\title{
Vietnamese Cultural Identity in the Process of International Integration
}

\author{
Nguyen Sy Trung*, Vu Hong Van \\ University of Transport and Communications, Vietnam
}

DOI: 1 10.36348/jaep.2020.v04i05.006 $\quad$ | Received: 16.05 .2020 | Accepted: 23.05 .2020 | Published: 27.05 .2020

*Corresponding author: Nguyen Sy Trung

\section{Abstract}

Culture plays an important role in the country's development process. The Communist Party of Vietnam has emphasized that culture is the spiritual foundation of society, both as a goal and a driving force of socio-economic development. In the process of international integration, the role of culture is shown more clearly. Currently, the Government of Vietnam is conducting a review of the Vietnam Cultural Development Strategy to 2020. Therefore, the accurate and objective assessment of cultural development over the past time is the scientific basis for policymaking for this particular area. This research focuses on analyzing opportunities and challenges with preserving and promoting the national cultural identity; the changes of national cultural values and the goals of promoting the national cultural identity of Vietnam in the process of international integration; at the same time, it suggested solutions to develop Vietnamese culture in the coming years.

Keywords: Vietnamese, Cultural, identity, international integration.

Copyright @ 2020: This is an open-access article distributed under the terms of the Creative Commons Attribution license which permits unrestricted use, distribution, and reproduction in any medium for non-commercial use (NonCommercial, or CC-BY-NC) provided the original author and sources are credited.

\section{INTRODUCTION}

The Communist Party of Vietnam has determined [1]: Culture is the spiritual foundation of society, the goal and driving force for sustainable development of the country. Culture must be placed on par with economy, politics, and society. Building an advanced Vietnamese culture imbued with national identity, united in the diversity of the Vietnamese ethnic community, with ethnic, human, democratic and scientific characteristics. Thus, culture has a special role in social life. Vietnamese culture has a long tradition of several thousand years of history [2]. Experiencing many wars, many ups and downs, crystallization and deposition of many positive values, such as patriotism and courage, high adaptability to change of circumstances, tolerance content, community spirit, kindness, optimism and kindness, respect for love, hard work, diligence. Currently, Vietnam is known by international friends as a peaceful, modern, youthful and dynamic country, an active member of international cooperation activities for peace and prosperity in the whole world [3, 4]. Moreover, the context of the landmark transformation of Vietnam, the "collision" between the new and the old creates a special attraction of Vietnamese culture [4]. The current culture is aiming to inherit traditional cultural values and at the same time absorb new values and look forward to the future, such as democracy, modernity, humanity, liberalization, tolerance and broadness [5]. Recognizing this basic feature and quality of Vietnamese culture in tradition and modernism will have a positive meaning, to transform it into the "soft power" of the country, creating persuasive power for international friends.

Globalization and international integration are taking place more and more strongly and deeply in the modern world, not only stopping in the economic field but also expanding, spreading and penetrating other fields of life, from society, environment to science, technology, culture, law, education, etc [5]. It is the process of impact and infiltration of globalization and international economic integration into all the fields of nations, where humanity is facing many important issues for the stability, existence and development of each nation and every region of the world in the relationships [6]. Global is taking place extremely rich and complex [5]. Globalization is both an opportunity for socio-economic integration and development, as well as great challenges, sometimes completely new, in terms of preserving, protecting, promoting and develop distinct, unique and traditional cultural values of each nation and nation in the context and new characteristics of the modern world [4].

The result of globalization is to create common values [5], to bring together, intertwined between the processes of development, especially in important areas such as economics, science and technology, However, globalization does not mean that all nations and peoples 
will come to uniformity in all aspects [4]. On the contrary, globalization can only take place when at the same time creating universal values for many nations and peoples, giving them good conditions and opportunities to promote and develop their own unique, unique and typical values. And that will take place not as a natural consequence of globalization, but necessarily a process of adjustment, cooperation and struggle of the nations and peoples participating in globalization. If this is not done, a dark and powerful force will take its course to drive the globalized "ship" in a way that destroys and weakens the unique cultural values of each nation will implement the scheme of imposing a culture, making other countries dependent, losing oneself in the modern world.

Vietnamese culture is strongly affected by globalization and international integration [4]. Therefore, to both integrate into the world economy, selective to absorb the cultural quintessence of humanity while preserving the traditional values of the nation is one of the difficult issues. Studying culture before globalization and international integration is a necessary issue, not easy and it takes time, perseverance and contribution of each citizen and the state.

\section{Opportunities and challenges with preserving and promoting the national cultural identity of Vietnam in the process of international integration}

Currently, Vietnam is actively and proactively integrating into the world, besides the opportunities and advantages, the challenges and difficulties created by integration are huge for all aspects of social life [1]. In the field of culture [4], it is even more profound, on the one hand, national culture has an opportunity to exchange and acquire the world's cultural quintessence, introduce and promote the special features of the national culture. But on the other hand, many of the cultural values that our nation takes thousands of years to create are being deformed, degraded, or even erased by the integration process itself [4]. That situation raises urgent requirements on how to maintain the identity, promote the beautiful values of national culture to serve the cause of national renewal and development.

International integration creates great opportunities for development, especially in terms of economy and technology, facilitating cultural exchanges, intelligence, experience, and transfer of modern technology, development of material civilization, creating a favorable environment for economic growth [5]. That is the integration process that makes the cooperation and division of international labor more and clearer [6]. As production specialization deepens, many countries participate in the production of a product, each of which becomes a stage of the production process [6]. Each country's economy is no longer purely only national. Thanks to international integration, the expanded communication network facilitates global networking; individuals can choose to exploit the data from the country's massive data banks [7]. International integration creates the ability to solve and handle in a global coordination major issues such as terrorism, environment, social evils, finance, and monetary [5].

However, the process of international integration is also revealing the negative and unpredictable threats to the peoples and underdeveloped countries [7]. That is the risk of assimilation, dissolution and loss of national cultural identity, weakening of national strength, leading to the risk of losing national sovereignty, etc. In fact, underdeveloped countries' development is partly concessions of interests, or subject to the economic, political and cultural penetration before major countries and developed countries. In the spiral of international integration, some countries have the throne but some countries are lagging behind, in the fierce competition on a global scale, the victory is in favor of developed countries or developing countries with preparation about internal resources, knowing how to choose a good path.

Politically, the process of international integration is the process of forming multi-polar, multicenter and temporary trends that increase the role of superpowers [5]. In recent years, some Western countries have used the guise of "democracy" and "human rights" to impose their standards and role models in relation to other countries. Taking advantage of their military and economic power, Western power centers attempt to take their standards as a condition of cooperation with other countries, forcing the least developed countries to depend on them, interfering in internal affairs of underdeveloped countries. The biggest difficulty currently facing small and underdeveloped countries is how to achieve economic growth while preserving and promoting the national cultural values, etc.

In the face of the multidimensional effects of such an international integration process, in order to counteract the legitimate integration trend of the world, another objective trend has formed and is becoming more capable. The latter, especially those countries with a rich history and culture, are planning their own strategies to protect and promote their national cultural identity, in order to find a reasonable path of development, the road combines the past with the future, the nation and the era.

Considering the opportunities and challenges created by the process of international integration with preserving the national cultural identity of Vietnam and promoting the values of the national culture, we see:

Opportunities: truly international integration has opened a new stage of development for Vietnamese national culture, creating conditions for the national 
culture to promote its hidden strengths, serving the cause of national construction and defense. The national culture of Vietnam, which has its roots and roots, has been experienced and challenged for thousands of years of building and defending the country, and has had a unique face and personality [4]. Until international integration took place, it was even more conditional to exchange with other cultures around the world. Thereby, continuing the quintessence, the value of human culture, enriching its identity, by adding to the national cultural value system, new elements rich in humanity and humanity [8]. It is a new source of spiritual energy, important for the national cultural body, contributing to the strength of the national culture, helping it to develop stronger. The process of international integration is also a favorable opportunity for us to promote and introduce to the world community about the image of the potential people of the country and rich national culture [8]. That is the best way to promote the values in the national cultural identity, and at the same time improve the self-defense ability of the national culture in the process of integration and contribute greatly to the cause industrialize and modernize the country.

Challenges: In the current process of international integration, Vietnam's national culture also faces many risks and obstacles to its development path. The values of national cultural identity, the factors that make up the intrinsic strength of Vietnamese national culture, of Vietnamese strength are facing great challenges. The beautiful values of the national cultural identity such as the national spirit whose core is patriotism, compassion, tolerance, respect for morality, morality, community cohesion, village affection neighbor, gratitude fellow, labor diligence and creative intelligence, etc. [9] was attacked, invaded from many sides. Good customs and practices are considered oldfashioned, out-of-date and unfashionable [8]. A part of the younger generation is busy chasing after the tastes of the time, the foreign culture, spreading foreign cultural products with unhealthy content. The most serious moral and ethical downturn was at an alarming level. First of all, the degradation of family morality, the relationship between children and parents, brothers and sisters are gnawing and losing for the sake of personal life [4]. Currently, in Vietnam, the standard of living of the whole society has been increasingly improved, a significant number of Vietnamese people are influenced by economic thinking, considering material value above all. People no longer judge people with virtues, ideals, heroes, altruism, etc. They judge people with a wealth of money, houses, cars, etc. Clearly, for these people, ethical and cultural standards are dangerously deflected. A significant part of the younger generation tends to negate the traditional culture, negate the moral values of ancestors, ancestors left, etc. The situation above is the risk of death national culture, limiting the development of rich Vietnamese culture and hindering the promotion of national cultural values in the process of international integration.

In addition, a significant challenge to Vietnam's national cultural identity in the process of international integration today is the "Strategy of peaceful evolution" [9] in the field of culture, which is hostile by the forces. Vietnam is trying to implement it, which they consider being a "war without gunfire" [4], a powerful weapon to sabotage Vietnam, which advocates enticing, win people and increase intensify their propaganda so that they are deeply imbued with "values Western", thus turning away from the traditional values of their own people, who always flatter Western societies as "civilized and free", "democratic", their culture is the highest and the most valuable [10]. Through the communication system, especially taking advantage of the rapid spread of a social network, these forces launched many campaigns against Vietnam's traditional national culture, in the form of "cultural exchanges" [10]. They tried to spread the so-called "freedom, democracy" in the "Western culture" into a part of the masses, especially the young, promotes the "new way of life" and is enamored with Western cultural activities. Through staff, students to study abroad, trainees working abroad to change ideas, to spread Western culture into Vietnam [10, 4]. In addition, they also through many forms such as tourist "tours", business cooperation to penetrate and spread Western culture in the heart of Vietnamese culture.

Thus, international integration is an inevitable historical trend that cannot be reversed. If not integrated into that trend, Vietnam has lost a great opportunity on its own to become rich and civilized. But participating in international integration poses significant challenges to our people, first and foremost, how to preserve the national cultural identity and promote strong Its value is to create momentum for the country's rapid and sustainable development with the goal: Rich people, strong country, democracy, justice and civilization.

\section{The change of national cultural values and the goal of promoting the national cultural identity of Vietnam in the process of international integration}

Culture is created by people [11], when socioeconomic conditions change, new values will be formed [12]. Due to changes in Vietnam's economic operation and international integration, it has made our society facing the values of modern world civilization. Along with the implementation of economic, political and cultural tasks in the new era, a series of new national values are forming. In which the old value is raised, the new value is recognized and built [13]. Here, both the old and the new are complementing each other to become a system of spiritual incentives to promote the nation's development. But how will we promote the power of that cultural value system to bring the highest efficiency? This is a big problem that is not easy to solve in a short time [4]. Through innovation, we have seen the need to both inherit the traditional cultural 
values of the nation and to selectively absorb the cultural values of humanity, but in reality, there are still many embarrassments. Faced with the new values formed since the renovation process up to now, at the same time facing the long-standing traditional values of the nation, it requires recognition, selection and operation. How to adapt it to current practice. The more accurate and timely the choice, the more it will benefit the country [10].

The renovation of more than 30 years has dramatically changed the awareness of morality and lifestyle on many characteristics of eating, wearing, staying, filial, happy, career, etc. with the development of analytical thinking, critique in every contemporary Vietnamese person has taken place the process of dissecting different types of social relations and at the same time the separation of values. As a result, it has promoted the process of innovation and diversification of value ladders among Vietnamese people. If the previous values are general and lackluster, now in Vietnam society has been shaping the main value groups such as Independence, freedom for the nation and people [1]; The value of peace, democracy and justice [4]; The value of being studious, attaching importance to education and respect for professional and technical occupations [8]; Value of employment and income; Value for money and wealth; Family value, happiness; Value of new social life; The value of personal beauty and the variety of beauty; Citizen values, personality values, etc.

Cultural value is a valuable asset of the nation [14], it is a strong spiritual motivation for the cause of national defense and construction, but it is the fruit of history [9]. If not developing, when referring only to the past, when praising is only praising the past. And so it is difficult to promote the motive role for the development of all aspects of the country in the current period [10]. Therefore, to be able to preserve, protect and promote the values of Vietnamese national culture practically and effectively, it is certain that these cultural values must be raised to a new level. The elements of Vietnamese culture such as patriotism, community, industrious virtues, simple lifestyles, etc. [4] have proved the vitality and strength in history, now in the process of international integration must be supplemented, completed and enhanced both in terms of content, direction and structure of its elements in new conditions and new practices.

The adding, completing and enhancing the value of traditional Vietnamese culture in the current period of renovation of international integration is nothing else, but rather absorbing the new values gained from when the country was renewed up to now [10]. That is the solid basis for the identity of the Vietnamese national culture not to become alien to the vivid reality in the new era, but also not to lose its own unique character, to be national, the science and the mass of the dialectic are intertwined in the Vietnamese culture of contemporary international integration. In order for the flow of Vietnamese national culture to always flow according to its campaign rules towards progress, civilization, to Truthfulness-Compassion-The beauty. In order to motivate the country to develop, it is necessary to continue updating the following elements:

Firstly, living with a high ideal: Belief and ideals have always been the strong motivation of our nation, the lofty ideal of a society of rich people, strong country, democracy, justice and civilization is still the goal, is a great motivation for the development of the country.

Secondly, scientific and dynamic thinking: Vietnam has participated in the extensive international integration process, how much knowledge and information is brought in every day, requiring a summary, generalization and treatment the reasoning at a high level, that is, there must be scientific thinking. Therefore, scientific thinking is a new requirement of our people in an upward trend, becoming a new value that requires awareness and promotion. Only building up dialectical, scientific and revolutionary thinking that takes real-life social life as a fulcrum to solve the great tasks set by the cause of national renovation and fulfill the ideal, goals of independence, progress, justice, democracy and civilization.

Thirdly, creativity in labor and cultural life activities. It is time to build up a Vietnamese mentality and a creative idea, so when working and organizing cultural life, they will delve into the object and find out appropriate ways to remove the conservative habits and prejudices that are deeply ingrained in our Vietnamese thinking and activities.

Fourthly, democracy and discipline in life and in social organizations. Democracy and democratic activities in our society have gradually been raised, but to achieve true democracy, there is still a need for greater efforts of the whole society. Therefore, it is necessary to view democracy as a new value to proactively realize and implement. Democracy must be associated with discipline and discipline of the State and society. Democracy cannot be confused with anarchist freedom, with what the individual wants to do. Therefore, culture must actively contribute to the building of civic consciousness.

Vietnam's goal is to build an advanced culture imbued with national identity, a culture that must be the spiritual foundation of society, both as a goal and a driving force for the country's development in the past process of innovation and international integration. To achieve that desire is not a simple task, because international integration is not only an opportunity but also a great risk to the national cultural identity. Therefore, in order to have more strength to overcome 
and continue to develop, the national cultural identity of Vietnam needs to inherit the traditional values of the national culture, selectively absorb the cultural elite of mankind, needs to add new valuable elements to enrich and enrich themselves. Integrating without dissolving the national cultural identity of Vietnam, at the same time affirming the bravery, appearance and essence of a dynamic, open culture, ready to exchange and share with the writing community Chemistry of the world, in the spirit of democracy, progress, justice and humanity is the motto of Vietnamese culture today.

\section{Some comments}

The process of globalization and international integration helps Vietnamese culture to have opportunities to spread widely in the world [4]. Vietnamese culture develops in the context that information technology has made great developments, globalization and international integration, which also opens up the possibility of cultural exchange, cooperation and development high chances of promoting Vietnamese culture to the world. Science technology, mass media development give people the ability to create and enjoy new cultural products quickly, efficiently and with high interactivity.

The Fourth Industrial Revolution and the digital economy create favorable conditions for the development of Vietnamese culture [10], helping us to exploit the economic potential of culture in a digital environment. The development of digital technology and digital technology has made it easier to access cultural contents and is not limited by national borders, which also requires differences and originality. In the content, the idea of cultural products as an important competitive advantage. Developed countries in the world are moving rapidly into the knowledge economy, creative economy, digital technology and digitization of cultural contents. These changes have brought about great opportunities for reducing production costs, contributing to creating distribution channels, promoting new products, requiring sharp actions and constant adaptation to change of environment. Digital transformation and entrepreneurship present new opportunities, capabilities and challenges for the cultural industry in terms of how it works.

The socialist-oriented market economy in our country has been creating social and cultural positives for the people, an opportunity to promote the people's autonomy and self-reliance in organizing activities and cultural creation [9]. People are increasingly encouraged to participate in social and cultural activities as proactive actors, from planning to assessing social and cultural issues, even as fellow citizens social and cultural creation with the state apparatus [1]. The endogenous factor of social and cultural development is highly increased, partly showing the increasing role of people compared to the State in many social and cultural issues.
The policy of active, comprehensive and comprehensive international integration of the Party and the State of Vietnam [1,9] has created favorable conditions for Vietnamese culture to integrate and develop. In the context of globalization, with the path of multilateralization and diversification of international relations, Vietnamese culture has a favorable opportunity to acquire advanced knowledge, resources and management experience quintessence of human culture and creation of new cultural values. In particular, the cultural industry is being oriented as one of the pillars of the economy. The economy is on the way of development, people's lives have been improved, forming a cultural consumer and enjoyment market with increasing demand [4], which is an important basis for promoting a culture of development.

\section{CONCLUSION}

Being deeply aware of those characteristics, challenges and laws of globalization, it is necessary to affirm that, in order to build an advanced Vietnamese culture imbued with national identity in the process of globalization, facing the challenges and complex impacts of globalization in the cultural field, we are ready and proactive to open, integrate and integrate into the general trend of the modern world and stand at the same time firmly on important principles, as a basis for taking advantage of opportunities, overcoming obstacles, challenges and self-reliance, proactively building the national culture with the strength, bravery and essence of the nation itself.

Opening, integrating, exchanging and cooperating in order to selectively acquire cultural and civilized values of humanity, at the same time, to protect and preserve the good, noble and national identity values of Vietnamese culture. Here, in the national culture, dialectic is expressed between the endogenous power and the capacity to receive, receive, or in other words, depending on the bravery and strength of our nation in the integration process and international exchange. "Protection of national identity must be associated with the expansion of international exchange, selective acquisition of good and progressive things in other ethnic cultures".

It is necessary to continue affirming that this is the principle and at the same time the bravery of our nation in the process of cultural exchange and international integration. Here, integration and exchange to both protect and make more sustainable cultural identities, at the same time richer, richer, more modern and the whole of our culture.

In order to be able to absorb the achievements, quintessence and cultural values of the outside while retaining the sovereignty and national cultural identity, making the national spirit and soul more profound in the process of delivery. Save, receive, and experience the long history of the Vietnamese nation has shown 
that the endogenous factors of our culture must play a decisive role. The stronger our internal power, the more opportunities and possibilities we have to receive, select and cooperate, meaning that that internal force will only coordinate relationships with exogenous factors and decide to choose filter and receive these elements, and at the same time have enough qualifications and bravery to "assimilate" the elements from the outside to become factors of the national culture itself, a catalyst for development more modern than that culture.

\section{REFERENCES}

1. Communist Party of Vietnam. (2016). The 12th National Delegation Congress. Hanoi: National Politics.

2. Giau, T. V. (1980). Traditional spiritual values of the Vietnamese. Hanoi: Social Sciences.

3. Binh, T. V. (1996). Ethnic culture in the process of renovation in Vietnam today. Hanoi: National Political.

4. Van, V. H. (2020). Redefining the role of culture in the renovation period in Vietnam. Hanoi: Police. IBSN: 978 - $604-72$ - 4319-8.

5. Gowan, P. (1999). The Global Gamble: Washington's Faustian Bid for World Dominance. London: Verso.

6. Ghose, Ajit, K. (2004). Global inequality and international trade. Cambridge Journal of Economics, 28(2), 229-252.
7. Meyer, John, W., John, Boli., George, M., Thomas., \& Francisco, O. Ramirez. (1997). World Society and the Nation-State. American Journal of Sociology, 103(1), 144-181.

8. Sadykova, R., Myrzabekov, M., Myrzabekova, R., \& Moldakhmetkyzy, A. (2014). The interaction of globalization and culture in the modern world. Procedia Social and Behavioral Sciences, 122(8), 8-12.

9. Communist Party of Vietnam. (2001). The 9th National Delegation Congress. Hanoi: National Politics.

10. Hoan, T. (1997). Preserving and promoting the national cultural identity is the basis to expand the door of exchange with other countries. Hanoi: Culture.

11. Them, T. N. (1997). Searching for Vietnamese Cultural Identity. Vietnam: Ho Chi Minh City.

12. Diem, N. K. (2002). Building and developing an advanced Vietnamese culture imbued with national identity. Hanoi: National Political.

13. Van, V. H., Long, N. T., Thanh, T. T., Dong, T. K., \& Luong, P. V. (2020). Folk Beliefs of Vietnamese People. India - United Kingdom: Book Publisher International. DOI: 10.9734/bpi/mono/978-9389816-92-1

14. Ngoc, P. (1998). Vietnamese Cultural Identity. Hanoi: Culture and Information. 